\title{
Glossary of Abbreviations and Terms
}

acta compromiso Commitment agreement

AD (Acción Democrática) Democratic Action, the social democratic party under Puntofijismo

Amor Mayor Bolivarian government mission providing pensions for poor elderly adults

ANC (Asamblea Nacional Constituyente) National Constituent Assembly

Araña Feminista The Feminist Spider, a national network of socialist feminist activists and organizations

BanMujer Woman's Development Bank

barrio Popular-sector neighborhood. Some barrios are quite large, with hundreds of thousands of people.

Barrio Adentro Bolivarian government mission providing free, communitybased primary health attention

BCV (Banco Central de Venezuela) Venezuelan Central Bank

Caracazo The popular uprising on February 27 and 28, 1989, in reaction to the introduction of a structural adjustment package, which was met with brutal state repression

CCT Conditional Cash Transfer

CFP (Círculos Femeninos Populares) Popular Women's Circles

Chavista The range of political forces aligned with Hugo Chávez from I998 to 2013

Chavismo The movement encompassing a range of forces in state and society aligned with Chávez from 1998 to 2013

Communal Council Legalized territorially based local communal government

CONAMU (Consejo Nacional de la Mujer) National Woman's Council 
CONG (Coordinadora de Organizaciones No-Gubermentales de Mujeres) Coordinating Committee of Women's Nongovernmental Organizations

COPEI (Comité Independiente Electoral) Independent Electoral Committee, the Christian Democratic Party under Puntofijismo

CPFMJ (Comisión Permanente de Familia, Mujer, y Juventud) National Assembly Permanent Commission on Family, Woman, and Youth

Economic Associative Unit Bolivarian government term for de facto organizations of two or more people administering a common economic project

EFOSIG (Escuela de Formación Socialista para la Igualdad de Género) School of Socialist Formation for Gender Equality

Falconiana A woman from Falcón state

FEVA (Federación Venezolana de Abogadas) Venezuelan Federation of Women Lawyers

Frente de Mujeres Women's Front

gobierneras Women perceived as servile and obedient to the government

Grupo Ese Group organizing for women's and LGBTTI rights in 2007 constitutional reform referendum

Hijos de Venezuela Conditional cash transfer program providing per child cash allowances to extremely poor households

IFI International financial institution

INaMujer National Woman's Institute

IVSS (Instituto Venezolano de Servicios Sociales) Venezuelan Institute of Social Services

IWD International Women's Day

LGBTTI Lesbian, gay, bisexual, transgender, transsexual, and intersex

LOSSS (Ley Orgánica del Sistema de Seguridad Social) Organic Social Security System Law

LSS (Ley de Servicios Sociales) Law of Social Services

MBR-200 (Movimiento Bolivariano Revolucionario-200) Bolivarian Revolutionary Movement-200

Mercal Bolivarian government mission distributing and selling low-cost basic food products

Mi Casa Bien Equipada Bolivarian government mission providing lowinterest credit from a state bank to purchase discounted household appliances

MinMujer Ministry for Woman's Popular Power and Gender Equality missions Set of Bolivarian government social and economic programs targeting the popular sectors 
MVR (Movimiento de la V República) Fifth Republic Movement

NGO Nongovernmental organization

oficialista Official

palanca lever, a term colloquially referring to someone with leverage or influence with state authorities

Patriotic Pole Electoral bloc coalition of actors, organizations, parties in support of Chávez

patrullera (Female) patrol officer in the PSUV

PDVSA (Petróleos de Venezuela) Venezuelan state oil company

Popular Sectors People from the poor and working classes

PSUV (Partido Socialista Unido de Venezuela) United Socialist Party of Venezuela

PT Pink Tide, a political term referring to new Latin American leftist governments in the twenty-first century

Puntofijismo Regime of governance from 1958 to 1998 premised on power sharing between AD and COPEI

Puntos de Encuentro (Encounter Points) Local groups of popular women organized by INaMujer

Red Todas Juntas All (Women) Together Network

Ribas Mission Bolivarian government mission providing free secondary education to adults

sector A smaller territorial unit within a barrio, such as the immediate neighborhood of several hundred people 
THIS PAGE INTENTIONALLY LEFT BLANK 
Engendering Revolution 
THIS PAGE INTENTIONALLY LEFT BLANK 